Article

\title{
How Do Dietary Choices Influence the Energy-System Cost of Stabilizing the Climate?
}

\author{
David Bryngelsson, Fredrik Hedenus *, Daniel J. A. Johansson, Christian Azar and \\ Stefan Wirsenius
}

Department of Energy and Environment, Chalmers University of Technology, 41296 Gothenburg, Sweden; david.bryngelsson@chalmers.se (D.B.); daniel.johansson@chalmers.se (D.J.A.J.);

christian.azar@chalmers.se (C.A.); stefan.wirsenius@chalmers.se (S.W.)

* Correspondence: hedenus@chalmers.se

Academic Editor: Robert Lundmark

Received: 9 December 2016; Accepted: 21 January 2017; Published: 5 February 2017

\begin{abstract}
We investigate how different global dietary scenarios affect the constraints on, and costs of, transforming the energy system to reach a global temperature stabilization limit of $2{ }^{\circ} \mathrm{C}$ above the pre-industrial level. A global food and agriculture model, World Food Supply Model (WOFSUM), is used to create three dietary scenarios and to calculate the $\mathrm{CH}_{4}$ and $\mathrm{N}_{2} \mathrm{O}$ emissions resulting from their respective food-supply chains. The diets are: (i) a reference diet based on current trends; (ii) a diet with high (reference-level) meat consumption, but without ruminant products (i.e., no beef, lamb, or dairy, only pork and poultry); and (iii) a vegan diet. The estimated $\mathrm{CH}_{4}$ and $\mathrm{N}_{2} \mathrm{O}$ emissions from food production are fed into a coupled energy and climate-system optimization model to quantify the energy system implications of the different dietary scenarios, given a $2{ }^{\circ} \mathrm{C}$ target. The results indicate that a phase-out of ruminant products substantially increases the emission space for $\mathrm{CO}_{2}$ by about $250 \mathrm{GtC}$ which reduces the necessary pace of the energy system transition and cuts the net present value energy-system mitigation costs by $25 \%$, for staying below $2{ }^{\circ} \mathrm{C}$. Importantly, the additional cost savings with a vegan diet--beyond those achieved with a phase-out of ruminant products-are marginal (only one additional percentage point). This means that a general reduction of meat consumption is a far less effective strategy for meeting the $2{ }^{\circ} \mathrm{C}$ target than a reduction of beef and dairy consumption.
\end{abstract}

Keywords: climate change mitigation; energy system modelling; dietary changes

\section{Introduction}

The global energy and food supply systems face substantial challenges over the 21st century, if global climate goals agreed to in the United Nations Framework Convention on Climate Change (UNFCCC) are to be met. A majority of existing scenarios developed using Integrated Assessment Models (IAMs) show that negative emissions of $\mathrm{CO}_{2}$ may be required during the second half of this century if the global mean surface temperature is to be stabilized below $2{ }^{\circ} \mathrm{C}$ above the pre-industrial level [1].

The majority of IAM studies have focused on how the energy system needs to be transformed [1], but it is clear that reducing greenhouse gas (GHG) emissions from the food supply system is critical [2-4]. Dietary changes can be an effective way of achieving emission reductions from the food supply system [3].

Currently, almost a quarter of global GHG emissions stem from agriculture and other land-use related activities [5]. Livestock account for more than half of these emissions [6]. While $\mathrm{CO}_{2}$ emissions from fossil sources dominate for the energy system, for the food-supply system, $\mathrm{CO}_{2}$ 
from land-use change, $\mathrm{CH}_{4}$ from anaerobic environments (irrigated rice production, rumination, and manure systems), and $\mathrm{N}_{2} \mathrm{O}$ from fertilizers are all major emission sources.

Reductions in emissions of $\mathrm{CH}_{4}$ and $\mathrm{N}_{2} \mathrm{O}$ affect the cost of climate stabilization [7]. Lower levels of non- $\mathrm{CO}_{2} \mathrm{GHG}$ in the atmosphere increase the cumulative carbon dioxide budget associated with a certain temperature stabilization level [8].

Vegetable food sources generally give rise to lower GHG emissions than animal-based food sources [9]. Several studies have investigated the large mitigation potential of dietary changes [2,3,10-15], Stehfest et al. [2] found that vegan and vegetarian diets could substantially reduce the cost of meeting a stabilization target of $450 \mathrm{ppm} \mathrm{CO}_{2}$-eq. However, less is known about how different dietary choices affect the cumulative carbon budgets for a given climate stabilization target and the consequences for the required energy system transformation. Reducing emissions from the agricultural sector could allow for more $\mathrm{CO}_{2}$ emissions from the energy system for a given climate stabilization level.

In this paper, we analyze these issues by connecting a model of the food-supply system with a fully coupled energy-climate-system optimization model. More precisely, we construct and assess three scenarios for food demand, one reference scenario, Reference, based on current trends, and two alternative scenarios that transition away from Reference, namely Non-ruminant, which transitions toward a diet high in pork and poultry meat, but without beef, dairy or other ruminant products; and Vegan, which transitions toward a vegan diet. In all three, we assume faster productivity increases in livestock productivity compared to the historical record, which reduces GHG emissions per meat and milk output, combined with extensive implementation of various technical mitigation options (e.g., low-emitting manure-management technology). These three scenarios are fed into the fully coupled energy-climate-system optimization model to assess the consequences of dietary developments for the transformation of the energy system and the associated mitigation costs for a given climate stabilization target. This paper aims to elucidate the effect of dietary changes on energy system transformation requirements under stringent climate targets and to highlight the indirect relationship between GHG emission abatement within the food supply system and the energy system.

\section{Method}

In the analysis, we link the World Food Supply Model (WOFSUM) [3], with the fully coupled global energy-transition-climate-system optimization model, GET-Climate [16]. With WOFSUM we construct three dietary scenarios and calculate $\mathrm{N}_{2} \mathrm{O}$ and $\mathrm{CH}_{4}$ emissions along the food supply chains. The three agricultural $\mathrm{N}_{2} \mathrm{O}$ and $\mathrm{CH}_{4}$ emission pathways all include similar exogenous technological developments in the food production system. Hence, they only differ in terms of dietary developments and the resulting $\mathrm{N}_{2} \mathrm{O}$ and $\mathrm{CH}_{4}$ emissions. These $\mathrm{N}_{2} \mathrm{O}$ and $\mathrm{CH}_{4}$ emission pathways are subsequently fed into GET-Climate in order to estimate the impacts of these diets and their emission pathways on the least-cost energy system, given a global climate stabilization target.

\subsection{Energy System Model GET-Climate}

The integrated energy system and climate model, GET-Climate [16] combines a bottom-up energy system model [17-21]. The energy system and climate models are hard-linked, which enables us to generate internally consistent least-cost scenarios for the global energy system for each dietary scenario, for a given climate goal. The optimization of the energy system is based on perfect foresight. The temperature limit places an upper constraint on the global temperature change over the whole modeling time horizon (2010-2170), i.e., temperature overshoot is not allowed.

The energy system part of the model represents five end-use sectors: electricity, transport, feedstock, residential-commercial heat, and industrial process heat. Demand projections are based on the MESSAGE B2 scenarios with a stabilization level of $480 \mathrm{ppm} \mathrm{CO}_{2}$-eq by 2100 [22]. The main energy supply and technology options are represented, such as fossil fuels, renewables, nuclear power, and bioenergy. Further, the future transport system is represented in some detail, with plug-in-hybrids 
and electric, fuel-cell, and biofuel vehicles. Conversion of primary energy to biofuels, hydrogen, and coal-to-liquids are represented, as well as the option of applying carbon capture and storage (CCS) to fossil fuels or to bioenergy (BECCS). Each technology is represented with data on costs, efficiencies, load factors, and carbon emissions. Total available non-renewable resources are included as well as maximum annual availability of renewables. Resource estimates are based on the reference [23]. In addition, various restrictions on technologies, e.g., limits for intermittent electricity supply, are included. For further details, see reference [19].

All major GHGes and aerosols are included in the climate model, and the carbon cycle representation takes climate feedback and nonlinearities into account, along with $\mathrm{CO}_{2}$ fertilization in the terrestrial biosphere and carbonate chemistry in the ocean [24]. Agricultural GHG emissions and mitigation measures are imported from the WOFSUM scenarios.

The net present value (NPV) of energy system mitigation costs over the period 2010-2170 is estimated for the three dietary scenarios. These costs are subsequently compared to the NPV of global aggregate GDP over the period 2010-2170 using the Intergovernmental Panel on Climate Change (IPCC) B2 scenario [22] extrapolated from 2100 to 2170. We choose a 5\%-per-year discount rate to estimate NPV (see online supplementary material (OSM) 1 for further discussion) to facilitate comparisons with other studies assessing the global cost of meeting concentration or temperature goals, e.g., in reference [1].

We run all scenarios with a climate sensitivity of $3{ }^{\circ} \mathrm{C}$ per $\mathrm{CO}_{2}$-eq doubling. This implies, in rough terms, a $50 \%$ probability of staying below the temperature limit, where the probability level can be determined through an assessment of probability density functions of climate sensitivity [25]. $\mathrm{CH}_{4}$ and $\mathrm{N}_{2} \mathrm{O}$ emissions from sources other than the energy system or agriculture are based on representative concentration pathway (RCP) 2.6 [26].

\subsection{World Food Supply Model}

The WOFSUM [3] is a simulation model that calculates global GHG emissions based on dietary scenarios. In the model, eight types of food are represented, cereals (and rice as a separate category); pulses and seeds; vegetable oils; other vegetables; dairy; ruminant meat; and other meat (mainly pork and poultry meat). $\mathrm{N}_{2} \mathrm{O}$ emissions associated with fertilizer and manure application are estimated by calculating the required nitrogen input in crop and pasture production given the nitrogen content in the required biomass output and the nitrogen utilization efficiency of the applied nitrogen. $\mathrm{CH}_{4}$ emissions from enteric fermentation are estimated as a fraction of feed intake in energy terms [27]. For $\mathrm{N}_{2} \mathrm{O}$ and $\mathrm{CH}_{4}$ from manure management, we estimate the fractions of different manure handling systems in different regions (based on [27]). The model can also include climate mitigation technologies that reduce emissions compared to baseline estimates.

For enteric fermentation as well as manure production, the main determinants of emissions are feed-efficiency and feed-rations. In most regions, feed efficiency in livestock systems has increased in the last decades, yet the potential for feed efficiency improvements is still significant in many systems [28-30]. Increased efficiency would reduce the GHG emissions per unit, especially for meat and milk [4,31]. Based on reference [28], we estimate a maximal feed efficiency that is close to the biological limit for each livestock category and assume that most regions converge linearly toward this level by 2100 and maintain it until 2170, see OSM. For Sub-Saharan Africa, South Asia, and Pacific Asia, which have had rather stable feed efficiencies for the past 40 years, we instead make the optimistic assumption that half the gap between the level of efficiency in 2000 and maximal efficiency is closed by 2100 .

Feed-rations for intensive production of pork and poultry are similar all over the world [32,33]; we assume that from 2100 and onwards the feed rations will be the same in all regions and that the feed efficiency will have reached its maximal potential, converging linearly until 2100 . The situation is more complicated for ruminants, as the feed rations not only depend on feed efficiency, but also on 
regional conditions and traditions. WOFSUM uses a simple model to estimate future feed rations for ruminant systems, described in OSM.

\subsection{Scenarios}

\subsubsection{Dietary Scenarios}

In this study, we created three dietary scenarios: one reference scenario, Reference, and two with lower GHG emissions, Non-ruminant and Vegan. Reference is based on baseline projections by FAO until 2050 [34], with regional data from reference [35] for the base year 2000 and extrapolations from 2050 to 2170 based on reference [3].

The low-emissions diets, Non-ruminant and Vegan, entail a gradual phase-out of food products from ruminants (i.e., beef, lamb, dairy) and animals, respectively. Non-ruminant has aggregate calories from meat consumption at the same level as Reference, but all ruminant meat is replaced over time by poultry meat, and dairy products are replaced with vegetable oil (1/3 in terms of energy) and legumes $(2 / 3$ in terms of energy). Vegan replaces dairy as above, but legumes replace meat products with a 1:1 ratio in terms of protein.

The Non-ruminant and Vegan diets are implemented over time with a logistic function (S-curve), locked at Reference levels until 2020. The transition reaches $50 \%$ by $2040,95 \%$ by 2060 , and goes asymptotically towards $100 \%$, see Figure S1, OSM.

\subsubsection{Dedicated Agricultural Technical Mitigation Measures}

Important technical mitigation options exist for several agricultural sources of GHG emissions [30,36-38], e.g., feed additives that reduce methane production in cattle and nitrification inhibitors that reduce nitrous oxide emissions from the soil. However, many of these measures are still at the experimental or pilot-scale levels, and long-term performance has yet to be proven. Overall potentials for many measures are also limited [39].

Based on an assessment of mitigation options presented in the academic literature, we assume that technical measures for GHG mitigation in agriculture are implemented in all three scenarios, using the same parameters. Based on reference [3] we assume that nitrification inhibitors will be available and have the potential to reduce nitrous oxide emissions by $20 \%$. We assume that all regions use this technology on $80 \%$ of nitrous oxide sources from fields by 2100 , and assume a linear introduction from today. $\mathrm{CH}_{4}$ emissions from ruminants can be reduced by roughly $20 \%$ with feed-additives [37]. We assume that feed-additives start to be used in Organization for Economic Cooperation and Development (OECD) regions in 2030, and in 2050 in non-OECD regions, for all non-pasture feed intake. We further assume a linear increase to $100 \%$ in all regions by 2100 . For rice, we assume a $66 \%$ reduction in emissions per $\mathrm{kg}$ produced by the year 2100 .

\subsubsection{Bioenergy Potentials}

We use an upper bound for the bioenergy potential of 150 EJ per year, with about $60 \mathrm{EJ}$ from agriculture and forestry residues and waste, and the remainder from bioenergy plantations. This assumption is roughly compatible with the land requirement in Reference, in line with, e.g., [40-42] while at the conservative end of the long-term bioenergy potential reported in references [43,44]. Less cropland and pasture is likely needed in Non-ruminant and Vegan as a result of higher field-to-plate efficiency. However, we still assume the same bioenergy potentials for all our scenarios since the focus is on the effect of reducing $\mathrm{CH}_{4}$ and $\mathrm{N}_{2} \mathrm{O}$ emissions, not land-use aspects.

How fast the model reaches the full bioenergy potential, if at all, depends on endogenous prices in the energy system model, i.e., endogenous prices on bioenergy, conventional energy sources, and $\mathrm{CO}_{2}$ emissions. 


\section{Results}

\subsection{Emissions from Dietary Scenarios}

The scenarios that phase out ruminant products have lower levels of $\mathrm{CH}_{4}$ and $\mathrm{N}_{2} \mathrm{O}$ emissions than Reference, see Figure 1. As expected, the differences in $\mathrm{CH}_{4}$ emissions in Reference compared to Non-ruminant and Vegan are large, due to the dominant role of ruminants for agricultural $\mathrm{CH}_{4}$ emissions. For Non-ruminant and Vegan the differences are small and determined by $\mathrm{CH}_{4}$ emissions from pork production and manure management. The remaining $\mathrm{CH}_{4}$ emissions in Vegan originate from irrigated rice production. For $\mathrm{N}_{2} \mathrm{O}$, the emissions are instead different for all three scenarios. For Reference and Non-ruminant, the difference in $\mathrm{N}_{2} \mathrm{O}$ emissions is primarily a result of the lower feed-crop demand in poultry production than in ruminant meat production, i.e., poultry's much higher feed-to-plate efficiency. The difference between Non-ruminant and Vegan is primarily a result of vegan products having still higher feed-to-plate efficiency than poultry and pork and, therefore, lower $\mathrm{N}_{2} \mathrm{O}$ emissions. The lower $\mathrm{CH}_{4}$ and $\mathrm{N}_{2} \mathrm{O}$ emissions result in lower atmospheric concentrations of $\mathrm{CH}_{4}$ and $\mathrm{N}_{2} \mathrm{O}$, which in turn means lower radiative forcing from these gases.
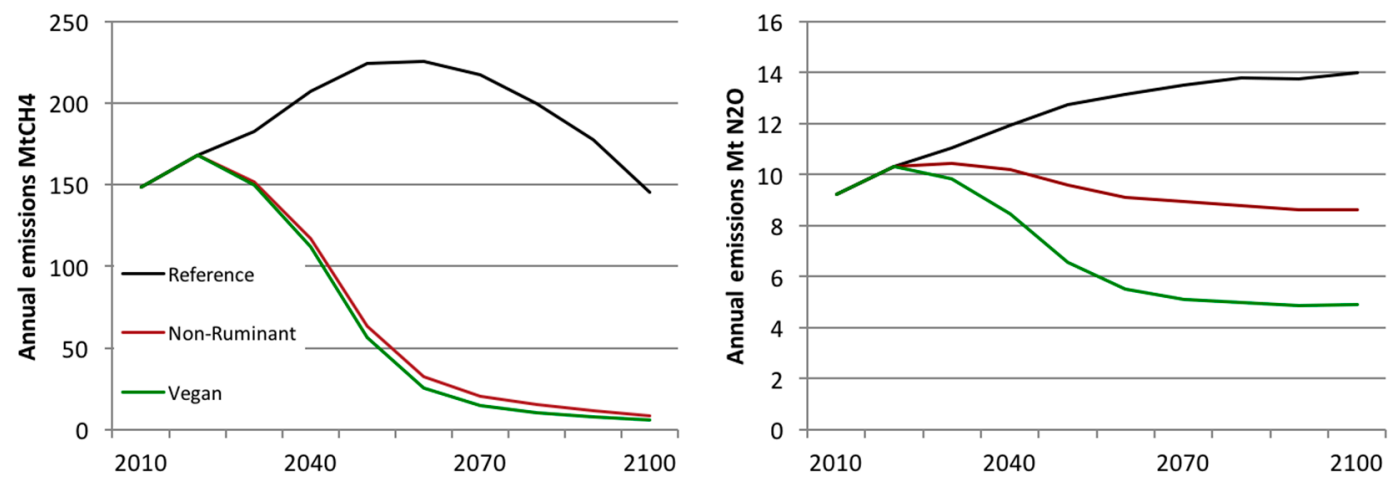

Figure 1. Annual emissions of methane (left) and nitrous oxide (right) from agriculture for each scenario, as calculated by World Food Supply Model (WOFSUM).

\subsection{Temperature Effect Due to Dietary Change}

There is a strong almost linear relationship between cumulative $\mathrm{CO}_{2}$ emissions and the increase in the global mean surface temperature [45]. In addition to the temperature rise caused by $\mathrm{CO}_{2}$ emissions, other GHGes and climate forcers have an impact on the global mean surface temperature. For a given amount of cumulative $\mathrm{CO}_{2}$ emissions, lower future levels of $\mathrm{CH}_{4}$ and $\mathrm{N}_{2} \mathrm{O}$ emissions imply a smaller change to the future surface temperature [8]. Figure 2 shows how the dietary shifts analyzed in this study lead to lower levels of future $\mathrm{CH}_{4}$ and $\mathrm{N}_{2} \mathrm{O}$ emissions, resulting in a temperature peak that is about $0.4{ }^{\circ} \mathrm{C}$ lower than for Reference for a given cumulative amount of $\mathrm{CO}_{2}$ emissions. Or analogously, a shift of diets to Non-ruminant or Vegan from Reference contributes to the possibility to emit more $\mathrm{CO}_{2}$ (about $250 \mathrm{GtC}$ ) for a given temperature limit, since the warming contribution from $\mathrm{CH}_{4}$ and $\mathrm{N}_{2} \mathrm{O}$ is smaller. There is thus a substitution in mitigation between sectors, with less mitigation in the energy system and more in the food system. Note the striking similarity between Non-ruminant and Vegan; both reduce the peak temperature by about $0.4{ }^{\circ} \mathrm{C}$ relative to Reference, for a wide range of $\mathrm{CO}_{2}$ emission trajectories, see Figure 2. 


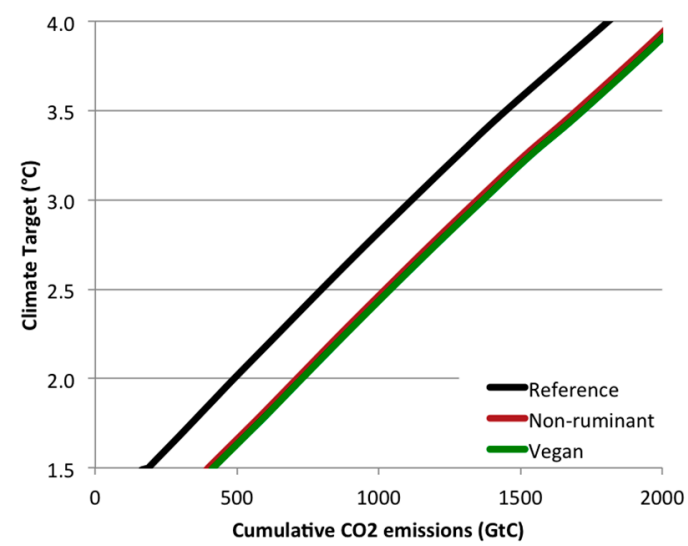

Figure 2. Temperature change as a function of cumulative $\mathrm{CO}_{2}$ emissions beyond 2010, depending on diet. All scenarios use the same optimistic assumptions on developments in agriculture regarding productivity and mitigation measures.

\subsection{Timing of Mitigation Measures}

For a given climate stabilization level, less radiative forcing from $\mathrm{CH}_{4}$ and $\mathrm{N}_{2} \mathrm{O}$ means more "room" for $\mathrm{CO}_{2}$ emissions. This in turn implies that the energy transition away from fossil fuel technologies with high $\mathrm{CO}_{2}$ emissions can be delayed, with correspondingly higher annual $\mathrm{CO}_{2}$ emissions during the transition period. Figure 3 a shows how the $\mathrm{CO}_{2}$ emissions differ over time for the different diets, for an approximate $50 \%$ chance of staying below $2{ }^{\circ} \mathrm{C}$ of warming. As seen in the figure, the $\mathrm{CO}_{2}$ emissions are clearly lowest for Reference, because of its higher non- $\mathrm{CO}_{2}$ emissions, while the $\mathrm{CO}_{2}$ emissions are only marginally higher in Vegan than in Non-ruminant. This points to the critical impact of $\mathrm{CH}_{4}$ emissions from ruminants. Figure $3 \mathrm{~b}$ shows that the temperature approaches $2{ }^{\circ} \mathrm{C}$ for all three scenarios, but that the temperature paths towards the temperature stabilization level are different. Most notably, Reference approaches the temperature limit slower than the other two scenarios. One reason is the inertia in the energy system due to the long life time of capital stocks.

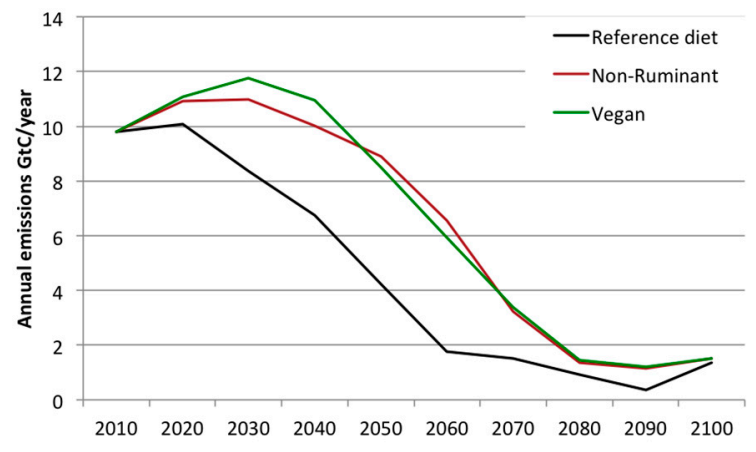

(a)

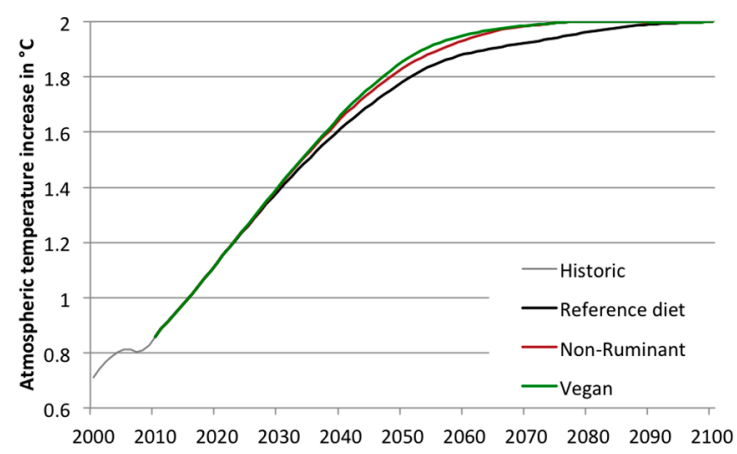

(b)

Figure 3. (a) Annual net $\mathrm{CO}_{2}$ emissions for the different diets for a binding $2{ }^{\circ} \mathrm{C}$ target; and (b) temperature profiles for the different diets. $\mathrm{CO}_{2}$ emissions (for the energy system) are higher for the non-ruminant and vegan diets, due to a substitution in mitigation between the energy system and the food system.

\subsection{Energy System Development}

The increased space for $\mathrm{CO}_{2}$ emissions made possible in Non-ruminant and Vegan has implications for the energy system and the energy supply mix, see Figure 4a-d. 


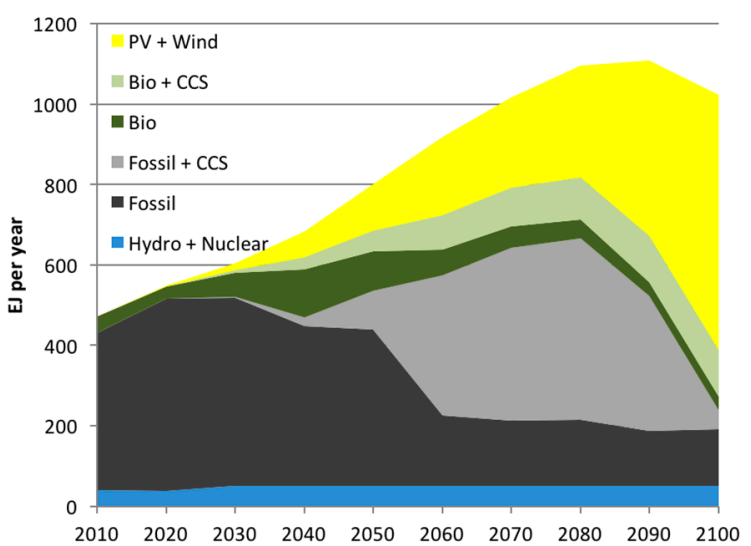

(a)

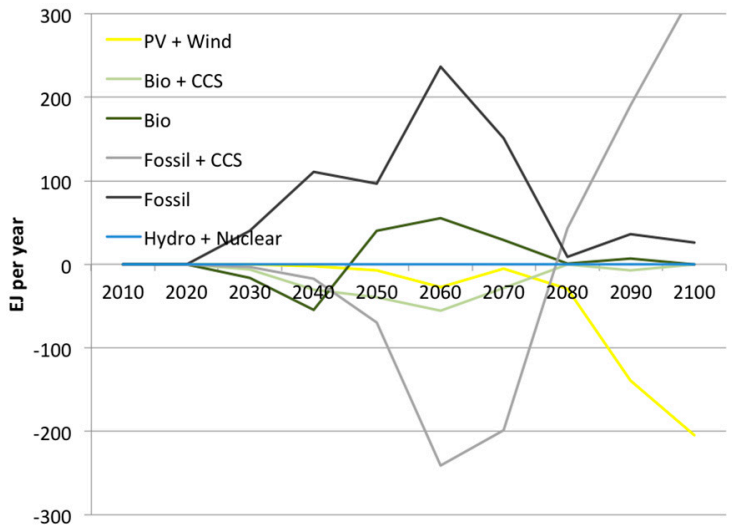

(c)

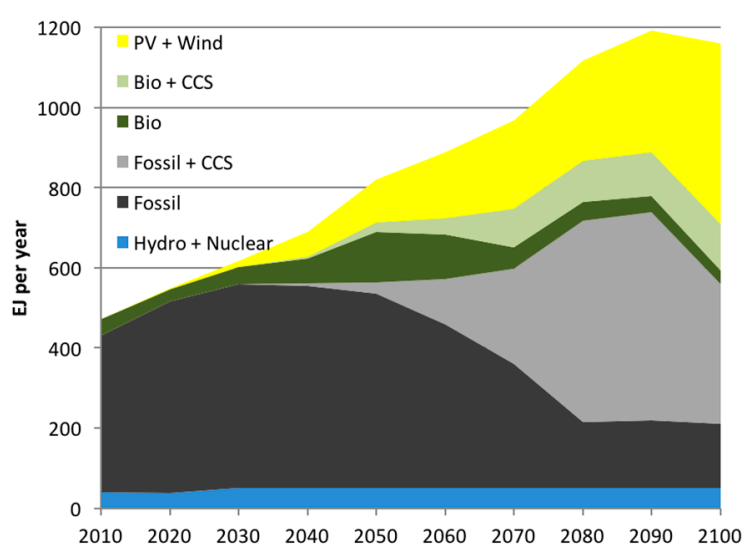

(b)

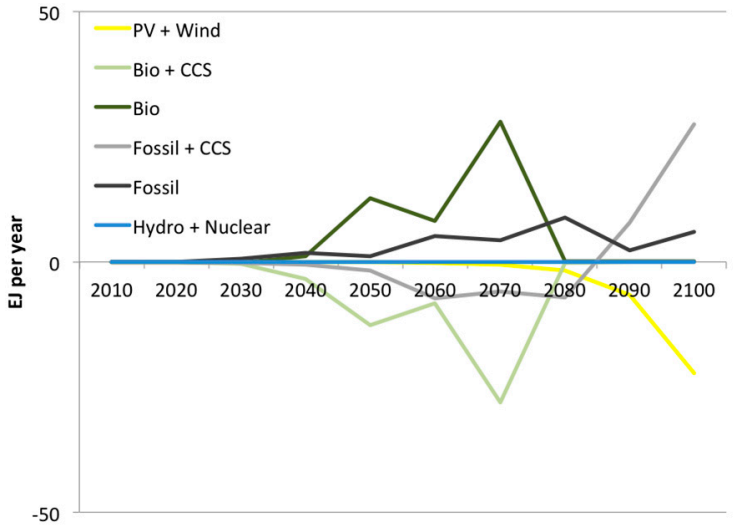

(d)

Figure 4. (a) Global primary energy supply in EJ/year for staying below the $2{ }^{\circ} \mathrm{C}$ limit with the reference scenario; (b) global primary energy supply in EJ/year for staying below the $2{ }^{\circ} \mathrm{C}$ limit with the non-ruminant scenario; (c) difference between the model output shown in Figure $4 \mathrm{~b}$ and that in Figure $4 a$, i.e., the difference between the energy systems in the non-ruminant and reference scenarios; and (d) same as (c) but for the difference between the vegan and non-ruminant scenarios. Note the difference in scale compared to $(\mathbf{d})$.

Figure 4 a depicts the least cost global primary energy supply over the 21st century for a $50 \%$ probability of staying below the $2{ }^{\circ} \mathrm{C}$ limit, while following the reference diet. Figure $4 \mathrm{~b}$ shows similar results for the non-ruminant scenario. The energy system development for Vegan is similar to that for Non-ruminant, since $\mathrm{CO}_{2}$ emissions are rather similar, and can be found in the OSM, Figures S2 and S3.

There are clear differences between Reference and the other two scenarios, including the much earlier and greater penetration of wind and solar energy (Figure 4c). Further, CCS is implemented earlier in Reference than in the others, while fossil fuels without CCS are used for a longer time in Non-ruminant and Vegan compared to in Reference. That difference peaks around 2060, with over 200 EJ more fossil fuels per year without CCS used in the alternative scenarios than in Reference. Note that the aggregate calories from meat consumption are the same in Reference and Non-ruminant. Hence, shifting away from ruminant products (beef, lamb, dairy, etc.) has a much stronger effect on the climate and aggregated emissions pathways for meeting climate stabilization targets than shifting from monogastric meat (poultry, pork) to vegan food.

\subsection{Energy System Cost}

For a given climate stabilization level, Non-ruminant and Vegan allow for higher cumulative $\mathrm{CO}_{2}$ emissions and a delayed energy system transition, compared to Reference. Consequently, 
Non-ruminant and Vegan entail lower mitigation costs for the energy system. With the reference diet, the energy-system mitigation costs are estimated at 1.42\% of the NPV of future global GDP for a temperature limit of $2{ }^{\circ} \mathrm{C}$ above the pre-industrial level (over the period 2010-2170), while these costs decrease to $1.07 \%$ and $1.04 \%$ with Non-ruminant and Vegan, respectively. These figures correspond to relative mitigation-cost reductions of $25 \%$ and $26 \%$. Figure 5 shows that the costs for the energy system transition increase over time for all scenarios, but faster for Reference than the other scenarios.

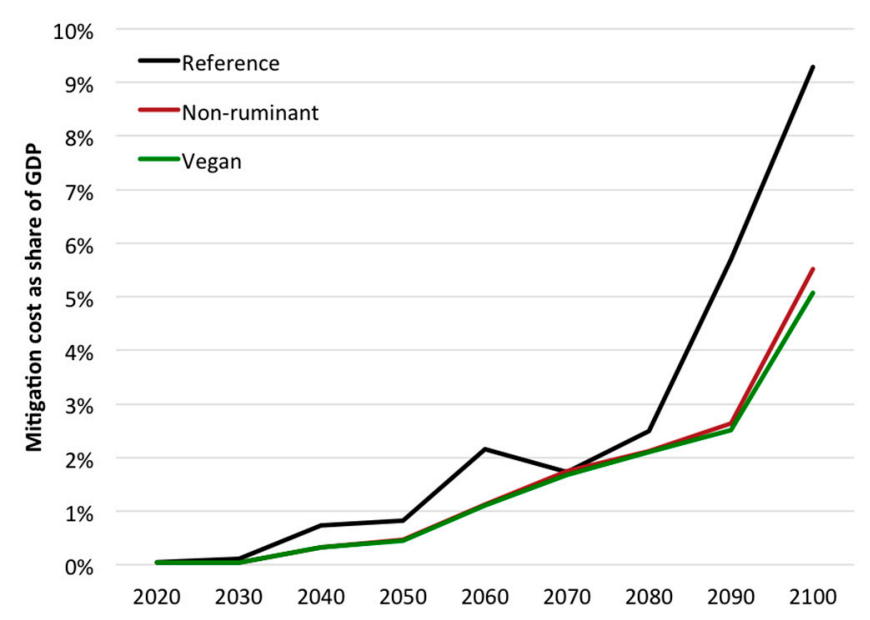

Figure 5. Mitigation costs for the energy system as share of GDP over time.

For a wide range of global temperature targets the mitigation costs are lower for Non-ruminant and Vegan than for Reference, see Figure 6. The reason for this is the larger cumulative $\mathrm{CO}_{2}$ emission space in the alternative dietary scenarios results in lower cost of the energy transition in NPV terms. The absolute savings are higher the more stringent the target, but the relative savings are almost constant.

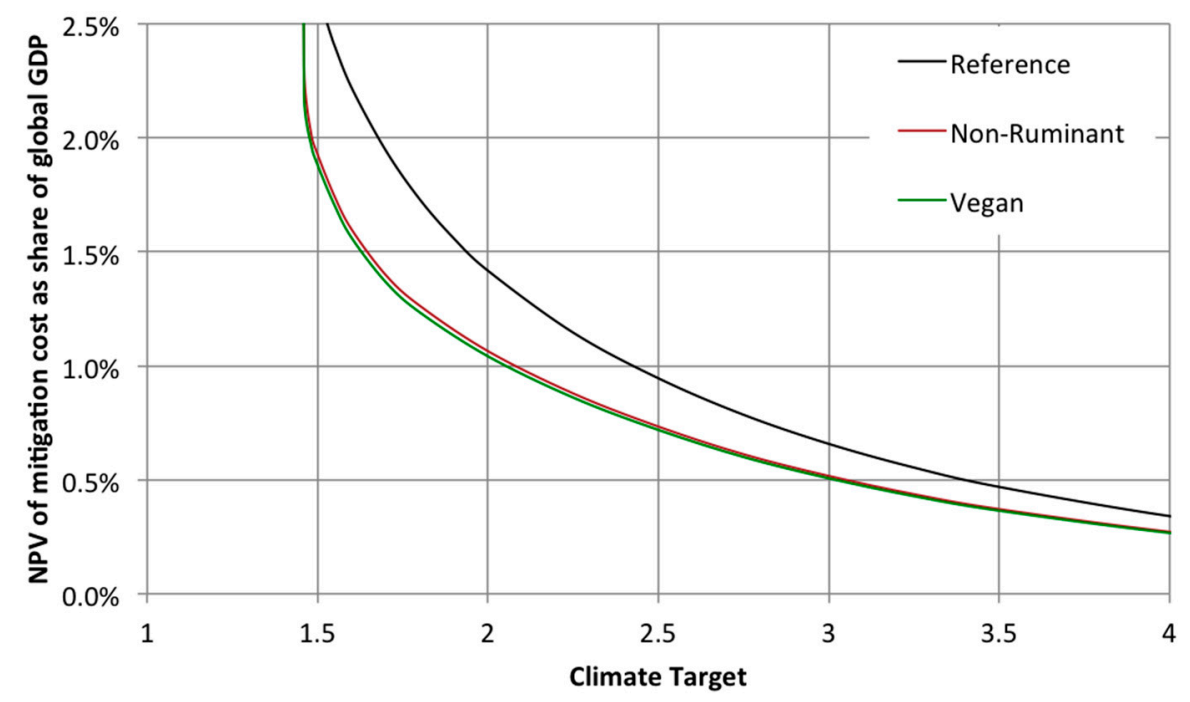

Figure 6. Energy system costs for climate change mitigation as a function of climate target, for the three dietary scenarios. The horizontal axis spans binding climate targets in ${ }^{\circ} \mathrm{C}$ warming compared to pre-industrial levels. The vertical axis represents the net present value (NPV) of additional energy system costs for reaching each climate target, as a share of the NPV of future global GDP.

Further, the diets differ on the levels at which the curves go asymptotic (Figure 6). Climate targets to the left of the vertical asymptotes are not possible to reach in the model. Therefore, stringent climate 
targets may require dietary shifts. Relatedly, if climate sensitivity is higher than $3{ }^{\circ} \mathrm{C}$ per $\mathrm{CO}_{2}$-eq doubling dietary shifts may be required for managing a temperature stabilization at $2{ }^{\circ} \mathrm{C}$ above the pre-industrial level.

For any given abatement cost, a more stringent target can be met in the alternative dietary scenarios than in Reference. For example, for an abatement cost of $1 \%$ of the NPV of global GDP, Reference affords a $50 \%$ chance of stabilizing the temperature at about $2.4{ }^{\circ} \mathrm{C}$ above the pre-industrial level, while Vegan and Non-ruminant afford the same chance for $2.1^{\circ} \mathrm{C}$.

\section{Discussion}

This study focuses on how different developments in agricultural emissions of $\mathrm{CH}_{4}$ and $\mathrm{N}_{2} \mathrm{O}$ affect the $\mathrm{CO}_{2}$ emission space and therefore the energy-system transition and its associated mitigation costs. Our findings corroborate [2]: it is not the quantity of meat that determines food-related GHG emission levels; it is the quantity of ruminant products, i.e., beef, lamb, and dairy. A switch from diets rich in ruminant meat to diets with meat from monogastric animals (pork, chicken) reduces $\mathrm{CH}_{4}$ emissions by almost the same amount as a switch to an entirely vegan diet and $\mathrm{N}_{2} \mathrm{O}$ emissions by about half the reduction achieved by switching to the vegan diet, in line with references [46,47].

The timing of the dietary transition is crucial when using an optimization model with binding temperature levels to assess the impacts of cumulative emissions of $\mathrm{CO}_{2}$ and energy system mitigation costs. The alternative diet scenarios analyzed in this paper provide an extra $\mathrm{CO}_{2}$ emissions space of $250 \mathrm{GtC}$ for the energy system, which is what yields the mitigation transition cost savings. However, in order for the trade-off to be of this magnitude, the food system changes have to take place before temperatures bump up against the limit. In our scenarios, the shift towards alternative diets start 2020 and is realized to $95 \%$ by 2060 . If the onset of the dietary shift is delayed, the potential for trade-offs between food-system and energy-system emissions is smaller, and consequently the mitigation cost benefits for the energy system will be smaller. Delaying the dietary transition means temporarily overshooting the temperature limit, if the emissions space calculated for a non-delayed transition is used. The temperature would peak at a level depending on the delay; beyond the peak, the temperature would move towards the targeted stabilization level, at a rate primarily dependent on the length of the delay and the removal rates of $\mathrm{CH}_{4}$ and $\mathrm{N}_{2} \mathrm{O}$ from the atmosphere.

Less optimistic assumptions regarding developments in agriculture would result in higher non- $\mathrm{CO}_{2}$ emissions for the reference diet. This would require earlier and faster mitigation in the energy sector with correspondingly higher costs and increase the risk of not achieving the climate targets. The benefits of dietary changes would thus be greater with more conservative assumptions about agricultural development.

In this study, we did not explicitly model emissions from land-use changes associated with the dietary change scenarios. In addition to lower $\mathrm{CH}_{4}$ and $\mathrm{N}_{2} \mathrm{O}$ emissions, a shift to a non-ruminant diet would reduce the grassland areas under grazing [28]. These lands could potentially be used for carbon sequestration through afforestation [48] or for lignocellulosic bioenergy crops, such as grass. Such developments would bolster the GHG mitigation effects of ruminant-free dietary scenarios, further reducing energy-system mitigation costs.

The increased consumption of pork and poultry at the expense of beef and lamb in the non-ruminant scenario would likely not increase global demand for cropland, since, on average globally, beef and lamb require about as much cropland per calorie as pork and poultry [49] in addition to their pasture land. Similarly, the increased consumption of legumes and vegetable oils as substitutes for animal products in the dietary scenarios are also unlikely to result in increased cropland use, since cropland requirements for legumes and vegetable oils are on a par with or below those for animal products [50]. Hence, it is reasonable to assume that there would be no significant cropland expansion in our dietary change scenarios; if anything, the opposite would be more likely.

We have not included the potential welfare loss from not eating ruminant meat and dairy products. Welfare losses of changing diets could be especially pronounced if the changes are imposed, e.g., 
through policy, rather than voluntary via changes in preferences. However, food preferences change over time, and such a welfare loss may only be transient, since consumers adapt [51]. We have also not included the impacts that changed diets could have on farmers' and land owners' profits. The likely reduced demand for pasture and crops would probably reduce total profits for farmers and land owners. It could be that the welfare losses of giving up ruminant meat and dairy outweigh the benefits achieved by relaxing the energy system transition requirements. For a $2{ }^{\circ} \mathrm{C}$ limit, the mitigation cost savings correspond to less than three quarters of a percent of the NPV of global GDP; society may prefer a higher energy system transition cost to dietary change.

Further, we have not included any positive effects from lower human consumption of red meat, although these may balance or outweigh the potential welfare loss mentioned above [52] nor have we included any added value of biological preservation (biodiversity) from the likely reduced demand for land resulting from the alternative diets.

\section{Conclusions}

In this paper, we assess how the energy system costs for meeting climate targets are affected by developments in global diets, given the potential mitigation trade-offs between the energy system and agricultural system. We investigate the difference in emissions between a reference diet and two diets that phase out ruminant products, one rich in non-ruminant meat and the other vegan. We assess the implications of the lower greenhouse emissions of the non-reference diets for the energy system transition, as these lower emissions allow the energy sector to instead emit a bit more, for a given climate target. Assumptions of efficiency improvements and technical mitigation measures in agriculture are optimistic and equivalent in all the scenarios. Our main findings are:

- A shift from the reference diet to an alternative diet devoid of ruminant products significantly reduces the energy-system cost of meeting binding climate targets. For a $2{ }^{\circ} \mathrm{C}$ target, the reduction in NPV is roughly $25 \%$. Moving to an entirely vegan diet only improves the cost reduction by one more percentage point.

- The main reason for the lower cost is that for a given climate stabilization level, we can emit more $\mathrm{CO}_{2}$ from the energy system if $\mathrm{CH}_{4}$ and $\mathrm{N}_{2} \mathrm{O}$ emissions are reduced. Hence, the energy system transition can be delayed and be more gradual in the scenarios that phase out ruminant products.

- The reduction in $\mathrm{CH}_{4}$ and $\mathrm{N}_{2} \mathrm{O}$ emissions in the alternative dietary scenarios results in an increase in the cumulative carbon budget equal to about $250 \mathrm{GtC}\left(900 \mathrm{GtCO}_{2}\right)$, which is about $60 \%$ higher than in the reference scenario.

- For even more stringent climate targets, the absolute cost savings are greater, and dietary changes may be required to meet the targets whatsoever. This also applies if climate sensitivity is greater than $3{ }^{\circ} \mathrm{C}$ of warming per $\mathrm{CO}_{2}$-equivalent doubling (for which the probability is roughly $50 \%$ ). Likewise, the impact of dietary change on mitigation costs and feasibility is greater if we require a higher probability of meeting a given target.

- Phasing out ruminant products has a substantial impact on energy-system mitigation costs irrespective of whether the new diets are rich in non-ruminant meat (i.e., rich in pork and poultry) or are vegan. The amount of meat in the diet is not of central importance; the amount of ruminant product is.

Our study suggests that a global shift towards more climate-friendly diets entails significant potential cost reductions in conjunction with a given climate mitigation goal. This result is robust over a wide span of climate goals.

Supplementary Materials: The following are available online at www.mdpi.com/1996-1073/10/2/182/s1.

Acknowledgments: The authors wish to thank the Swedish Energy Agency, E.ON, Adlerbertska Research Foundation, and Carl Bennet AB for financial support. We would also like to thank Niclas Mattson for valuable technical support. 
Author Contributions: Christian Azar had the idea, David Bryngelsson performed the modeling with contributions by Fredrik Hedenus; David Bryngelsson, Fredrik Hedenus, Daniel J. A. Johansson, Christian Azar and Stefan Wirsenius analysed the results, David Bryngelsson and Daniel J. A. Johansson wrote the paper with contributions from Fredrik Hedenus, Christian Azar and Stefan Wirsenius.

Conflicts of Interest: The authors declare no conflict of interest.

\section{References}

1. Clarke, L.; Jiang, K.; Akimoto, K.; Babiker, M.; Blanford, G.; Fisher-Vanden, K.; Hourcade, J.-C.; Krey, V.; Kriegler, E.; Lo'schel, A.; et al. Assessing transformation pathways. In Climate Change 2014: Mitigation of Climate Change; Edenhofer, O., Pichs-Madruga, R., Sokona, Y., Farahani, E., Kadner, S., Seyboth, K., Adler, A., Baum, I., Brunner, S., Eickemeier, P., et al., Eds.; Cambridge University Press: Cambridge, UK; New York, NY, USA, 2013.

2. Stehfest, E.; Bouwman, L.; Vuuren, D.P.; Michel, G.; den Elzen, J.; Eickhout, B.; Kabat, P. Climate benefits of changing diet. Clim. Chang. 2009, 95, 83-102. [CrossRef]

3. Hedenus, F.; Wirsenius, S.; Johansson, D.J.A. The importance of reduced meat and dairy consumption for meeting stringent climate change targets. Clim. Chang. 2014, 124, 79-91. [CrossRef]

4. Bryngelsson, D.; Wirsenius, S.; Hedenus, F.; Sonesson, U. How can the EU climate targets be met? A combined analysis of technological and demand-side changes in food and agriculture. Food Policy 2016, 59, 152-164. [CrossRef]

5. Intergovernmental Panel on Climate Change. Summary for policymakers. In Climate Change 2014: Mitigation of Climate Change; Edenhofer, O., Pichs-Madruga, R., Sokona, Y., Farahani, E., Kadner, S., Seyboth, K., Adler, A., Baum, I., Brunner, S., Eickemeier, P., et al., Eds.; Cambridge University Press: Cambridge, UK; New York, NY, USA, 2014.

6. Gerber, P.J.; Steinfeld, H.; Henderson, B.; Mottet, A.; Opio, C.; Dijkman, J.; Falcucci, A.; Tempio, G. Tackling Climate Change through Livestock; Food and Agriculture Organization of the United Nations (FAO): Rome, Italy, 2013.

7. Van Vuuren, D.P.; Weyant, J.; de la Chesnaye, F. Multi-gas scenarios to stabilize radiative forcing. Energy Econ. 2006, 28, 102-120. [CrossRef]

8. Rogelj, J.; Meinshausen, M.; Schaeffer, M.; Knutti, R.; Riahi, K. Impact of short-lived non- $\mathrm{CO}_{2}$ mitigation on carbon budgets for stabilizing global warming. Environ. Res. Lett. 2015, 10. [CrossRef]

9. Davis, J.; Sonesson, U.; Baumgartner, D.U.; Nemecek, T. Environmental impact of four meals with different protein sources: Case studies in Spain and Sweden. Food Res. Int. 2010, 43, 1874-1884. [CrossRef]

10. Risku-Norja, H.; Kurppa, S.; Helenius, J. Dietary choices and greenhouse gas emissions-assessment of impact of vegetarian and organic options at national scale. Prog. Ind. Ecol. Int. J. 2009, 6, 340-354. [CrossRef]

11. Berners-Lee, M.; Hoolohan, C.; Cammack, H.; Hewitt, C.N. The relative greenhouse gas impacts of realistic dietary choices. Energy Policy 2012, 43, 184-190. [CrossRef]

12. Saxe, H.; Larsen, T.M.; Mogensen, L. The global warming potential of two healthy Nordic diets compared with the average Danish diet. Clim. Chang. 2012, 116, 249-262. [CrossRef]

13. Ekström, S. Greenhouse Gas Emissions and Food Consumption: A Study of Sustainable Food Habits in Sweden; Stockholm University: Stockholm, Sweden, 2012.

14. Westhoek, H.; Lesschen, J.P.; Rood, T.; Wagner, S.; de Marco, A.; Murphy-Bokern, D.; Leip, A.; van Grinsven, H.; Sutton, M.A.; Oenema, O. Food choices, health and environment: Effects of cutting Europe's meat and dairy intake. Glob. Environ. Chang. 2014, 26, 196-205. [CrossRef]

15. Hallström, E.; Carlsson-Kanyama, A.; Börjesson, P. Environmental impact of dietary change: A systematic review. J. Clean. Prod. 2015, 91, 1-11. [CrossRef]

16. Azar, C.; Johansson, D.J.; Mattsson, N. Meeting global temperature targets-The role of bioenergy with carbon capture and storage. Environ. Res. Lett. 2013, 8. [CrossRef]

17. Azar, C.; Lindgren, K.; Andersson, B.A. Global energy scenarios meeting stringent $\mathrm{CO}_{2}$ constraints-Cost-effective fuel choices in the transportation sector. Energy Policy 2003, 31, 961-976. [CrossRef]

18. Azar, C.; Lindgren, K.; Larson, E.; Möllersten, K. Carbon capture and storage from fossil fuels and biomass-Costs and potential role in stabilizing the atmosphere. Clim. Chang. 2006, 74, 47-79. [CrossRef] 
19. Hedenus, F.; Karlsson, S.; Azar, C.; Sprei, F. Cost-effective energy carriers for transport-The role of the energy supply system in a carbon-constrained world. Int. J. Hydrog. Energy 2010, 35, 4638-4651. [CrossRef]

20. Johansson, D.J.A.; Persson, U.M.; Azar, C. The cost of using global warming potentials: Analysing the trade off between $\mathrm{CO}_{2}, \mathrm{CH}_{4}$ and $\mathrm{N}_{2}$ O. Clim. Chang. 2006, 77, 291-309. [CrossRef]

21. Johansson, D.J.A. Temperature stabilization, ocean heat uptake and radiative forcing overshoot profiles. Clim. Chang. 2010, 108, 107-134. [CrossRef]

22. International Institute for Applied Systems Analysis. GGI Scenario Database, 2nd ed. Available online: http://www.iiasa.ac.at/web-apps/ggi/GgiDb/dsd?Action=htmlpage\&page=regions (accessed on 28 November 2014).

23. Global Energy Assessment (GEA) Group. Global Energy Assessment_-Toward a Sustainable Future; Cambridge University Press: Cambridge, UK; International Institute for Applied Systems Analysis: Laxembourg, 2012.

24. Joos, F.; Bruno, M.; Fink, R.; Siegenthaler, U.; Stocker, T.F.; le Quéré, C.; Sarmiento, J.L. An efficient and accurate representation of complex oceanic and biospheric models of anthropogenic carbon uptake. Tellus $B$ 1996, 48, 397-417. [CrossRef]

25. Bindoff, N.L.; Stott, P.A.; AchutaRao, K.M.; Allen, M.R.; Gillett, N.; Gutzler, D.; Hansingo, K.; Hegerl, G.; $\mathrm{Hu}$, Y.; Jain, S.; et al. Detection and attribution of climate change: From global to regional. In Climate Change 2013: The Physical Science Basis; Stocker, T.F., Qin, D., Plattner, G.-K., Tignor, M., Allen, S.K., Boschung, J., Nauels, A., Xia, Y., Bex, V., Midgley, P.M., Eds.; Cambridge University Press: Cambridge, UK; New York, NY, USA, 2013.

26. Van Vuuren, D.P.; Stehfest, E.; Elzen, M.G.J.; Kram, T.; van Vliet, J.; Deetman, S.; Isaac, M.; Goldewijk, K.K.; Hof, A.; Beltran, A.M.; et al. RCP2.6: Exploring the possibility to keep global mean temperature increase below $2{ }^{\circ} \mathrm{C}$. Clim. Chang. 2011, 109, 95-116. [CrossRef]

27. Eggleston, H.S.; Buendia, L.; Miwa, K.; Ngara, T.; Tanabe, K. IPCC Guidelines for National Greenhouse Gas Inventories; Institute for Global Environmental Strategie (IGES): Kanagawa, Japan, 2006.

28. Wirsenius, S.; Azar, C.; Berndes, G. How much land is needed for global food production under scenarios of dietary changes and livestock productivity increases in 2030? Agric. Syst. 2010, 103, 621-638. [CrossRef]

29. Bajzelj, B.; Richards, K.S.; Allwood, J.M. Importance of food-demand management for climate mitigation. Nat. Clim. Chang. 2014, 4, 924-929. [CrossRef]

30. Bennetzen, E.H.; Smith, P.; Porter, J.R. Decoupling of greenhouse gas emissions from global agricultural production: 1970-2050. Glob. Chang. Biol. 2016, 22, 763-781. [CrossRef] [PubMed]

31. Valin, H.; Havlik, P.; Mosnier, A.; Herrero, M.; Schmid, E.; Obersteiner, M. Agricultural productivity and greenhouse gas emissions: Trade-offs or synergies between mitigation and food security? Environ. Res. Lett. 2013, 8. [CrossRef]

32. Steinfeld, H.; Gerber, P.; Wassenaar, T.; Castel, V.; Rosales, M.; de Haan, C. Livestock's Long Shadow. Environmental Issues and Options; Food and Agriculture Organization of the United Nations: Rome, Italy, 2006.

33. MacLeod, M.; Gerber, P.; Mottet, A.; Tempio, G.; Falcucci, A.; Opio, C.; Vellinga, T.; Henderson, B.; Steinfeld, H. Greenhouse Gas Emissions from Pig and Chicken Supply Chains-A Global Life Cycle Assessment; Food and Agriculture Organization of the United Nations (FAO): Rome, Italy, 2013.

34. Prospects for Food, Nutrition, Agriculture and Major Commodity Groups. World Agriculture: Towards 2030/2050; Food and Agriculture Organization of the United Nations (FAO): Rome, Italy, 2006.

35. The Statistical Database of the Food and Agriculture Organization (FAO); FAO: Rome, Italy, 2011.

36. Akiyama, H.; Yan, X.; Yagi, K. Evaluation of effectiveness of enhanced-efficiency fertilizers as mitigation options for $\mathrm{N}_{2} \mathrm{O}$ and $\mathrm{NO}$ emissions from agricultural soils: Meta-analysis. Glob. Chang. Biol. 2010, 16, 1837-1846. [CrossRef]

37. Grainger, C.; Beauchemin, K.A. Can enteric methane emissions from ruminants be lowered without lowering their production? Anim. Feed Sci. Technol. 2011, 166-167, 308-320. [CrossRef]

38. Montes, F.; Meinen, R.; Dell, C.; Rotz, A.; Hristov, A.N.; Oh, J.; Waghorn, P.; Gerber, J.; Henderson, B.; Makkar, H.P.S.; et al. SPECIAL TOPICS-Mitigation of methane and nitrous oxide emissions from animal operations: II. A review of manure management mitigation options. J. Anim. Sci. 2013, 91, 5070-5094. [CrossRef] [PubMed]

39. Smith, P.E.; Martino, D.; Cai, Z.; Gwary, D.; Janzen, H.; Kumar, P.; McCarl, B.; Ogle, S.; O’Mara, F.; Rice, C.; et al. Greenhouse gas mitigation in agriculture. Philos. Trans. R. Soc. B Biol. Sci. 2008, 363, 789-813. [CrossRef] [PubMed] 
40. Erb, K.-H.; Haberl, H.; Plutzar, C. Dependency of global primary bioenergy crop potentials in 2050 on food systems, yields, biodiversity conservation and political stability. Energy Policy 2012, 47, 260-269. [CrossRef] [PubMed]

41. Popp, A.; Dietrich, J.P.; Lotze-Campen, H.; Klein, D.; Bauer, N.; Krause, M.; Beringer, T.; Gerten, D.; Edenhofer, $\mathrm{O}$. The economic potential of bioenergy for climate change mitigation with special attention given to implications for the land system. Environ. Res. Lett. 2011, 6, 034017. [CrossRef]

42. Smith, W.K.; Zhao, M.; Running, S.W. Global bioenergy capacity as constrained by observed biospheric productivity rates. BioScience 2012, 62, 911-922.

43. Intergovernmental Panel on Climate Change. Special Report on Renewable Energy Sources and Climate Change Mitigation; Cambridge University Press: Cambridge, UK; New York, NY, USA, 2011.

44. Smith, P.; Bustamante, M.; Ahammad, H.; Clark, H.; Dong, H.; Elsiddig, E.A.; Haberl, H.; Harper, R.; House, J.; Jafari, M.; et al. Agriculture, Forestry and Other Land Use (AFOLU). In Climate Change 2014: Mitigation of Climate Change; Edenhofer, O., Pichs-Madruga, R., Sokona, Y., Farahani, E., Kadner, S., Seyboth, K., Adler, A., Baum, I., Brunner, S., Eickemeier, P., et al., Eds.; Cambridge University Press: Cambridge, UK; New York, NY, USA, 2014.

45. Collins, M.; Knutti, R.; Arblaster, J.; Dufresne, J.-L.; Fichefet, T.; Friedlingstein, P.; Gao, X.; Gutowski, W.J.; Johns, T.; Krinner, G.; et al. Long-term climate change: Projections, commitments and irreversibility. In Climate Change 2013: The Physical Science Basis; Stocker, T.F., Qin, D., Plattner, G.-K., Tignor, M., Allen, S.K., Boschung, J., Nauels, A., Xia, Y., Bex, V., Midgley, P.M., Eds.; Cambridge University Press: Cambridge, UK; New York, NY, USA, 2013.

46. Bows-Larkin, A.; McLachlan, C.; Mander, S.; Wood, R.; Röder, M.; Thornley, P.; Dawkins, E.; Gough, C.; O'Keefe, L.; Sharmina, M. Importance of non- $\mathrm{CO}_{2}$ emissions in carbon management. Carbon Manag. 2014, 5, 193-210. [CrossRef]

47. Eshel, G.; Shepon, A.; Makov, T.; Milo, R. Land, irrigation water, greenhouse gas, and reactive nitrogen burdens of meat, eggs, and dairy production in the United States. Proc. Natl. Acad. Sci. USA 2014, 111, 11996-12001. [CrossRef] [PubMed]

48. Humpenöder, F.; Popp, A.; Dietrich, J.P.; Klein, D.; Lotze-Campen, H.; Bonsch, M.; Bodirsky, B.; Weindl, I.; Stevanovic, M.; Müller, C. Investigating afforestation and bioenergy CCS as climate change mitigation strategies. Environ. Res. Lett. 2014, 9. [CrossRef]

49. Herrero, M.; Wirsenius, S.; Henderson, B.; Rigolot, C.; Thornton, P.; Havlík, P. Livestock and the environment: What have we learned in the past decade? Annu. Rev. Environ. Resour. 2015, 40, 177-202. [CrossRef]

50. Ranganathan, J.; Vennard, D.; Waite, R.; Lipinski, B.; Searchinger, T.; Dumas, P.; Forslund, A.; Guyomard, H.; Manceron, S.; Marajo-Petitzon, E.; et al. Shifting Diets for a Sustainable Food Future; World Resources Institute: Washington, DC, USA, 2016.

51. Bowles, S. Endogenous preferences: The cultural consequences of markets and other economic institutions. J. Econ. Lit. 1998, 36, 75-111.

52. Perignon, M.; Vieux, F.; Soler, L.G.; Masset, G.; Darmon, N. Improving diet sustainability through evolution of food choices: Review of epidemiological studies on the environmental impact of diets. Nutr. Rev. 2017, 75, 2-17. [CrossRef] [PubMed]

(C) 2017 by the authors; licensee MDPI, Basel, Switzerland. This article is an open access article distributed under the terms and conditions of the Creative Commons Attribution (CC BY) license (http://creativecommons.org/licenses/by/4.0/). 